\title{
Preparing the Learners for the Future - What is Crucial beyond the Grade 12 Certificate
}

\author{
DR FA Naude \\ Central University of Technology, Free State \\ Email: fnaude@cut.ac.za
}

Doi:10.5901/mjss.2014.v5n27p438

\begin{abstract}
The importance of preparing learners for the world of work, is often under discussion. Nevertheless, besides the fact that articles underlining problems in this regard appear often, the process and challenges of choosing a career wisely and correctly , seems to remain. Concerns that people will not reach their full potential in a career because of a lack of interest, aptitude , general ability or sufficient achievement to be accepted in academic or training programmes, don't solve the problem something practical will have to be done. The guidance received in the existing Life Orientation programmes done at school seems to be inadequate or are not applied correctly. Problems such as ill-equipped teachers and other educational challenges contribute to the fact that career planning still does not receive the necessary attention. The reality of ill-equipped, unqualified workers lacking motivation and uninformed students lacking dedication and focus who see the university as the only way to success, will remain with us until we implement a strategy at school to inform, guide and evaluate learners to make decisions that will fit their potential , capabilities and interests. A study of reasons for the present state of affairs, the position of schools and their role and the best application process of informing the child as well as the possible contribution of tertiary institutions and industry will be of utmost importance to combat and solve this problem which is hampering healthy economic development in $S A$.
\end{abstract}

Keywords: Life Orientation, career guidance, model-c schools, Process orientated, Subject combination

\section{Introduction}

The importance of preparing learners for the world of work, is often under discussion and although articles underlining this problem often appear, the challenges of choosing a career wisely and correctly, seem to remain. The mere fact that there is a concern about people not reaching their full potential in careers due to inappropriate preparation and/or training for future careers or a shortfall in interest, aptitude, general ability, personality or academic/scholastic achievement when entering academic - or training programmes, does not solve the problem - something practical will have to be done.

The career guidance component in the Life Orientation programme in schools seems to be inadequate or is failing to give learners clear, scientifically based indicators in the career selecting process as will be discussed further on.

The reality of ill-equipped, unqualified workers lacking the necessary motivation and vision as well as the problem of uninformed students lacking dedication and focus who see the university as the only way to success, will remain with us until we implement a strategy at school to inform, guide and evaluate learners on solid grounds and with arguments to make decisions that will fit their potential, capabilities and interests.

A concerted effort will have to be made to provide the young people entrusted to the teaching practitioners with the necessary guidance, insight and vision to plan for the future and not only for the next class test, examination or school activity.

\section{Background}

Education in general and the teaching profession in particular, seem to make headlines very often in South Africa unfortunately for the wrong reasons. A very negative image has become synonomous with the profession in many schools and with the general public and taxpayer. Spaull (2013) writes. "An objective outsider would agree that the weight of available evidence favours judgement that our education system is in dire straits." The existing crises in vacant teaching posts which has risen from 10846 in January 2012 to 22051 in March 2012 and the subsequent filling of vacancies with temporary teachers of which only $41 \%$ seems to be qualified, only increases the negative perceptions further (Lovemore, 2012).

The mere preparation of the learner to obtain a grade 12 certificate, whether useful or not, cannot be tolerated. A 
matric certificate should not be the ultimate goal. Even more alarming - the decision by the Department of Basic Education to use question papers based only on the new Curriculum (Caps), for examinations from next year onwards, would mean that pupils who were in Gr 12 from 2008-2013 will not be able to repeat subjects to pass or improve marks. This would in fact mean that there is no or very little hope for Gr 12's who failed and this fact will only contribute to joblessness in SA (Byars, 2013).

There is a life beyond the grade 12 certificate and argumentation in favour of the preparation of the learner by dedicated and qualified teachers for the world of work, will be the main focus. By making a success of this goal, many other problems in schools will be solved. Only a few of the matters that should fall in place, will be concerns about discipline, subject choice and subject combinations, motivation and dedication. If you know where you are heading, your actions will be steadfast and directed. For this purpose, specific attention should be paid to career guidance and welltrained and interested teachers to drive this process.

\section{Overview of the Problem}

Bearing in mind the core business of formal education and teaching namely the full development of the learner socially, intellectually, physically and emotionally as well as the acquisition of general and specific skills and competencies, abilities and values, it is clear that the school, the profession and the teacher have a mammoth task in the preparation of the learner for the day he or she leaves the school premises for the last time as a learner. Mwamwenda (2004) states clearly that the success of counselors to assists learners to resolve their personal, social, vocational and educational problems, will determine the quality of learners that the school system will produce and that in turn will contribute to national and economic development.

In career guidance the young person musts be guided and assisted to solve own problems and to cope with independent maturity and its responsibilities. The young person must be able to make accountable, sensible, reliable and optimal occupational choices in accordance with his/her abilities and qualities bearing in mind his/her view of life and labour (Jacobs, Van Jaarsveld, and Von Mollendorf: 1991:199).

A serious matter that needs to be addressed, is the fact that many matriculants seem to be unable to choose a career. They begin to consider a vocation only after having received the matric results and it is then when you find many learners and parents who are very happy about their children who have passed, yet they do not know which direction to follow. "Our schools appear to be overlooking career guidance. This learning area has become a luxury of a few selected conscientious schools. It is not uncommon to find Grade 11 or 12 pupils who do not have a clue what they would like to do after matriculating. Foundations for the career choices should start from Grade 1. A solid foundation for the future starts there" (Msila, 2013). Byars (2013) states very clearly that if the youth wants to benefit from future opportunities, they will need good career guidance. She mentions that many parents rely on the school to supply the so needed career guidance. Pupils however, feel that schools do not meet the expectations. Msila (2013) also mentions that careers need to be chosen much earlier in the school career and not on the $13^{\text {th }}$ year. In this process effective career teachers can continuously work with parents as they learn and find out more about the children's strengths.

Career planning encompasses more than just finding a career, it also refers to future planning and in this parents, the teacher (career guidance teacher) and employer will play important roles "because there is a special relationship between future expectation and productivity" (Jacobs et al., 1991:199).

It is important that a learner's attitude towards school, study, teachers, school activities are all school related matters, which will determine his/her attitude towards life but also the world of work. The school should therefore create a work background which will promote positive qualities and values such as perseverance, initiative, good communication skills, sound co-operation with others, responsibility etc. to prepare the young person for the occupational world. (Jacobs et al., 1991).

Career guidance and counseling in general is also a means to assist learners to make wise and appropriate educational choices which will enable them to develop according to inherent potential. Access to career opportunities in line with individual potential, interest and abilities will be promoted and enhanced (Stringer \& Kerpelman, 2010).

The development of skills in almost all sectors of the economy in South Africa is of crucial importance because the skills shortage has reached crises proportions in South Africa (Calldo, 2010).

It has become evident from previous research that many young people leaving school opt for studies not leading to a specific profession or apply for studies where there is already an oversupply of people (The Development Policy Research Unit, 2007). Inadequate career guidance at secondary school level seems to be a reality when this phenomena occurs and this view point is also supported by the research done by Van der Venter (2006). 
Add to this the alarming dropout figures at universities, and a disturbing picture emerges. "Seven years after official data first revealed that about half of undergraduate students drop out of university without completing their degrees, new figures show no improvement in this poor academic performance," and educationists and students said that inadequate assistance, poor academic support and family pressure contributed to high dropout rates" (John, 2013).

\section{Theories Regarding Occupational Choice}

Various theories and factors regarding occupational choices have been developed and identified. Jacobs et.al. (1991) mention some of the theories which are found in subject literature in this regard. The first that should be noted is Crites (1969) who classified the various theories very broadly under non-psychological, psychological and general, while Weinrach (1979) basically distinguished two approaches, the process-oriented approach and the structural or incidental approach. Osipow (1983) on the other hand, warned against oversimplifying the process by categorizing the process of how a career is chosen.

For the purpose of this presentation brief notice will only be paid to the process-oriented approach and the structural approach.

According to the process-oriented approach, occupational choice is the result of consecutive decisions made during specific phases in a person's life and the importance of developmental tasks that an individual has to master during certain phases of his/her life to attain occupational maturity and consequently the readiness to make an informed career choice Occupational maturity in this regard can be seen as to refer to self-knowledge; knowledge about occupations; decision-making ability and the ability to integrate information and implement decisions.

In the Structural approach the relation between information about the individual and the world of work is of importance and for this purposes psychometric instruments are used to gather information while for the process-oriented approach the information obtained by psychometric testing is not linked to the so-called world of work. The processoriented approach supporters however do make allowance for psychometric testing.

To conclude on this matter, for the purpose of this presentation, "the interdependence of the process-orientated approach and the structural approach to occupational choice is also evident from the fact that an individual's level of occupational maturity is determined by means of so-called occupational maturity questionnaires." (Jacobs et.al., 1991:5)

\section{Scholastic and Educational Realities}

It is necessary to point out that the effective guidance of a learner for the world of word, encompasses more than just providing appropriate information about the variety of careers that exist, what they are all about and whether it fits in with the individual's psychological, non-psychological and general attributes and characteristics. Proper academic planning and guidance regarding the correct subject choice and general or specific academic achievement and performance should also be given. For the purpose of this presentation time will not be spent on the importance of choosing subjects in Grade 9, but it is necessary to bear this important facet in mind. Patton (2005) refers to an adopted definition by the Australian Education Council in 1992 where career education in 'Australian Schools is seen as a field or a service which concerns itself with the development of appropriate knowledge (information), skills and attitudes by means of a planned and structured programme of learning experiences which will assist learners to make informed decision about the school and after school options which will ensure effective participation in working life. The informed decisions about the school, inevitably refer to academic and educational matters such as subject choice combinations, effective study and admission requirement for further studies and the world of work. This is without doubt also applicable for South Africa.

Considering the present situation in South African schools regarding the provision of career guidance, it should be noted that provision is made for and time devoted to career planning in the Life Orientation programme offered at schools. Questions are however raised whether the programme is presented by appropriately trained people in a way that will benefit learners.

The Life Orientation programme aims at educating healthy, responsible young people who will be able to live productive lives in the new South African democracy (Jacobs, 2011:212). Considering this fact, it becomes clear that the country will be able to benefit socially, intellectually an economically.

The reality of findings reflected by different writers, own experience and superficial research done by the presenter, unfortunately paints a different picture.

According to findings by writers such as Jacobs (2011), Prinsloo (2007), Theron and Dalzell (2006) and Rooth (2005), teachers often feel that they have not been trained sufficiently to present the subject and furthermore "little evidence could be found which proves that Life Orientation achieves the aim as set forth in the National Curriculum 
Statement"

In a study by Jacobs (2011:217) to determine how learners experienced LO, the frequency of addressing learning outcomes showed that Career Choices featured once, compared to Health Promotion/Personal Development, 10 times; Social Development 5 times etc. It is therefore clear that LO hardly succeeds in addressing the need for career development and that little time was actually devoted to matters such as subject choice and its influence on further studies , career opportunities and the planning needed in this regard, the availability of training facilities, costs ,etc.

The Life Orientation Programme in South African schools deals with five different topics in Grades 7 to 9 and they include the development of the self in society, health and social responsibility, constitutional rights and responsibilities , physical education and the world of work (Department of Basic Education , 2011). Subject choices are made towards the end of Grade 9 and eleven hours are spent on career guidance covering seven topics. These topics are time management, reading and writing for different purposes, options available once Grade 9 is completed, knowledge of the world of work career and subject choices, study and career funding providers and planning for lifelong learning (Department of Basic Education , 2011).

When listening to the comments of some of the learners concerning LO, their views and even frustrations, can be easily understood. Although schooling has a formative and educative nature, with primary task that of teaching and learning, "effective educative teaching can only take place in a school when a teacher, with his or her superior knowledge and skills, meets pupils in the classroom, and accepts responsibility for the creation, progress and result of the teachinglearning situation." (Kruger \& Van Schalkwyk, 1997:12). All the years spent at school cannot, however, simply conclude in a goal of merely obtaining a school leaving or equivalent certificate. Schooling should serve as a preparation for life after school and specifically also as preparation for a future career. Bush and Anderson (2004:90-91), when discussing basic educational values that should be instilled in prospective educators, mention, amongst other qualities, the following that should filter through to the learners: the promotion of academic excellence, the education of learners to the best of their ability and the preparation of learners for life after school - by implication the world of study, training and work.

Jacobs (2011: 217-219) also encountered a very negative attitude concerning LO from learners, more so from previous Model-C schools. Learners' comments included remarks such as that it was a waste of time, that they had hardly learned anything, that LO or Life skills is something that your parents can teach you and also that the LO period was seen as a "free period" or "homework period". Theron \& Dalzell (2006:401) found that learners placed a high value on Career guidance. Unfortunately the emphasis seems to have been placed on other components of the subject - not that it should be considered unimportant.

In an attempt to determine whether what has been gathered from the academic research engaged in so far, it was decided to investigate and inquire into the practical and scholastic experiences of a group of Education III students regarding subject- and career guidance and information. An informal, short questionnaire was used to obtain the relevant information. Out of a group of 70 students, 40 were selected at random to complete the questionnaire anonymously and voluntarily. This group was decided on because of the good existing rapport that I have with them, their cooperative, critical and inquisitive participation in class discussions and the fact that, although they have settled down in higher education, they still have contact with senior learners at school, either as friends or through practical teaching and are still quite aware of own experiences at school.

Interesting information related to this study which became apparent, includes the following:

- More than half of the group (53\%) are studying education because they were either not accepted in their first choice (not having qualified for admission or course already full) or because education was the only course with vacancies available.

- At least half (50\%) would have chosen a different career if they had a subject choice enabling them to do so.

- $60 \%$ would have chosen a better subject combination if they have received better/more information regarding admission requirements and subject values.

- Only 10\% felt that they received adequate subject information to make a informed choice in Gr 9.

- Only $40 \%$ of the group replied that they received adequate information in Life Orientation in senior secondary school to make informed career decisions.

- Only 15\% felt that they received adequate information about specific admission requirements for different fields of study or careers.

- And $75 \%$ of the group indicated that subject- and career guidance should receive more attention at secondary school level.

The results obtained from the questionnaire completed by the Education III group and the lively discussion that followed when the outcomes were discussed was convincing proof that there are reasons for concern. 
Broadly summarized, the following alarming results confirmed what the literature research stated.

- More than half of the group (50-53\%) would have chosen a different field of study if their subject combination had enabled them to do so or if their first choice was possible. (Meaning if their subject choice allowed them and/or place was available)

- $60 \%$ would have chosen a different of "better" subject combination if they had received better and clearer information regarding the value of subjects and the relation to admission requirements.

- $75 \%$ of the group indicated that subject- and career guidance should receive more attention at secondary school level.

When considering all the findings, comments, results and practical circumstances that have been dealt with so far, it is evident that the existing situation in South African schools in so far as dealing with career- and subject guidance is far from what is needed to ensure that young people are properly prepared for the day that they will have to leave school.

In an interesting development related to this matter, the national minister of Basic Education in Souyh Africa , Minister Angie Motshekga, has received a report drawn up by leading education academics, where the position of Life Orientation as known now, could be drastically changed. Although no changes can take place overnight and the status quo is still intact, it is important to note that it is recommended that LO be abolished as an examination subject for Gr. 12. Parts of the subject such as career counseling and wellbeing should however be retained without examination according to the recommendations made. Furthemore the modernizing of vocational training, including the curriculum of technical schools, is recommended (Joubert, 2014).

\section{Conclusion and Recommendations}

All the years spent at school cannot and should not conclude in a goal of merely obtaining a school leaving or equivalent certificate.

In fulfilling its educational task of teaching and learning, the school does not only prepare the child for the world of work, but at the same time the career directed character of the process to develop knowledge, skills and attitudes, also gives direction and meaning to the learning process or experience.

The absence of Guidance as a subject, or even a service in the school, the inability of teachers due to lack of training, enthusiasm, dedication or what other reason to give appropriate guidance to learners in terms of their career planning, is neither to the advantage of the learners nor the teaching profession and the world of work.

Possible guidelines to combat existing problems concerning career guidance that have been indicated and discussed, should be considered because it is believed that adequate, properly planned and creatively constructed strategies to improve career guidance will not only improve the existing situation, but it could also lead to the opening up of debate amongst educators and that will benefit learners and the process of teaching and learning.

The following recommendations could serve as guidelines to counter existing problems until a better system can be established in schools.

- Parent involvement to inform learners about their personal careers and professions in terms of admission, training, working conditions etc.

- Involving trained people in LO programmes and allowing more time for career guidance and related matters.

- Using the services of recruitment and/or academic staff from universities, FET Colleges and representatives from industry to give information regarding artisans in various fields. Organised labour can play an important role to point out areas where workers are needed.

- Mobilise subject teachers to explain the career value of their subjects. Msila (2013) adds to this when he says that we need inventive teachers in our education system where every teacher becomes a career guidance educator. He emphasizes that teachers should be able to identify the talents of their learners.

Involve NGO's such as Pulse, EVA Solutions, Perfect Careers, PACE and others to assist in career guidance through existing programmes. Their assistance through internet information, work books, programmes such as Career Mapper etc. and the involvement of sponsoring companies can be of invaluable assistance (Kartus, 2012:2-3) to distribute information and assist in psychometric evaluation.

The success of the mentioned recommendations will largely depend on the appointment of an interested, willing and able staff member to act as co-ordinator to structure and execute all actions between the school and external participants.

To ensure equilibrium in the teaching/learning process and in the life of the learner, proper career preparation to emphasize that the ultimate goal of twelve years of schooling lies beyond the certificate at the end of Grade 12, should be given. 


\section{References}

Bush, T. \& Anderson, L. (2003). Organisational culture. In Coetzee, S.A. \& Van Niekerk, E.J. \& Wydeman, J.L. An Educators Guide to Effective Classroom Management. Revised Third Edition 2010.

Byars, P. (2013). Senior manager of the Gibs centre for leadership and dialogue in an Article on "So dink SA se Jeug oor hul Toekoms" in Volksblad 13 June 2013

Calldo F. (2010). Skills Shortages in South Africa: summary of facts per sector regarding this issue. Solidarity Research Institute.

Coetzee, S. A., Van Niekerk, E.J., Wyderman, J.L. (2010). An Educator's Guide to effective Classroom Management. Revised Third Edition. Van Schaik Publishers, Pretoria.

Crites, J.O. (1969). Vocational psychology. New York: McGraw-Hill Book Co. In Jacobs, C.D.,Van Jaarsveld, N.H. and Von Mollendorf, J.W.(1991). Career Guidance for Primary and High School. Teacher's Manual. Unibook Pulishers, Hatfield.

Department of Basic Education. (2011). Curriculum and Assessment Policy Statement Grades 7-9: Life Orientation. Pretoria: Government Printing Works.

Jacobs, A. (2011). Life Orientation as experienced by learners: a qualitative study in North-West Province. South African Journal of Education, 31(2), 212-223.

Jacobs,C.D. , Van Jaarsveld,N.H. and Von Mollendorf , J.W. (1991). Career Guidance for Primary and High School: Teacher's Manual. Unibook Publishers, Hatfield.

John, V. (2013). Article on Dropout rate points to lack of support. http://www.unisa.ac.za. Downloaded/retrieved 25 July 2013.

Joubert, J.J. (3 August 2014). Radical matric reform on the cards. Sunday Times.

Kartus, L. (2012). The Importance of Career Guidance \& its Impact On South African Business. http://www.workinfo.com/free/ downloads/276.htm?Back.x=12\&Back.y=15 Downloaded/Retrieved 28/08/2012.

Kruger, A.G., Van Schalkwyk, O.J (1997). Classroom Management. Van Schaik Publishers, $7^{\text {th }}$ impression 2011.

Lovemore, A. (22 August 2012). Vakante onderwysposte neem drasties toe. Volksblad.

Msila, V. Article on Teach Youth to think outside education box. The Star 9 April 2013. Retrieved 10 April 2013 http://www.iol.co.za/thestar/teach-youth-to-think-outside-education-box-1.1497643\#.UWQ-05PimeY

Mwamwenda, T.S. (2004). Educational Psychology, An African Perspective. (Third Edition). Heinemann Publishers.

Osipow, S.H. and Fitzgerald, L.F. (1996). Theories of Career Development(4 $4^{\text {th }}$ edition). Needham Heights. Mass:Allyn \& Bacon.

Patton, W. (2005). A postmodern approach to career education: what does it look like?: research article: narrative counselling. Perspectives in Education: Postmodern (Narrative) Career Counselling and Education: Special Issue 2(23).

Pauw, K., Oosthuizen, M., \& Van der Westhuizen, C. (2008). GRADUATE UNEMPLOYMENT IN THE FACE OF SKILLS SHORTAGES: A LABOUR MARKET PARADOX1. South African Journal of Economics, 76(1), 45-57.University of Cape Town.

Prinsloo, E. (2007). Implementation of life orientation programmes in the new curriculum in South African schools: perceptions of principals and life orientation teachers. South African Journal of Education, 27(1), 155-170.

Rooth, E. (2005). An investigation of the status and practice of Life Orientation in South African Schools in two provinces. (Doctoral Dissertation),. Cape Town: University of the Western Cape.

Spaull, N. (2013). Article on It's the teachers' lack of knowledge, stupid. http://www.timeslive.co.za/opinion/2013/08/22/it-s-the-teacherslack-of-subject-knowledge-stupid. Retrieved on 23 August 2013.

Stringer, K. J., \& Kerpelman, J. L. (2010). Career identity development in college students: Decision making, parental support, and work experience.Identity: An International Journal of Theory and Research, 10(3), 181-200.

Theron, L., \& Dalzell, C. (2006). The specific Life Orientation needs of Grade 9 learners in the Vaal Triangle region. South African journal of education, 26(3).

Van der Venter, A.M. (2006). Grade nine learners' experiences of career counseling at school. (Masters dissertation), Pretoria: University of South Africa.

Weinrach, S.G. (1979). Career Counseling: Theoretical and practical perspectives. New York: McGraw-Hill. In Jacobs, C.D., Van Jaarsveld, N.H. and Von Mollendorf. J.W. (1991). Career Guidance for Primary and High School: Teacher's Manual. Unibook Publishers (Pty) Ltd. Hatfield. 